\title{
Can the Balkans Join the West?
}

\begin{abstract}
Today, the Balkans-even the enduring trouble spots in Bosnia, Macedonia, Serbia, and Kosovo - are at peace. The region struggled through a violent post-Communist decade in the 1990s but in the early years of the new millennium made real progress in transitioning to more open, democratic societies. Balkans trade and finance are already linked to European markets, but the EU has stalled enlargement until 2025, when it intends to be ready to welcome additional Balkan members. Montenegro and Serbia lead the regatta, but both face major challenges in institutionalizing the rule of law. That is even more true of the laggards, Bosnia and Kosovo. While skepticism about qualifications and dates is justified, the incentive of EU membership is vital to driving continued reform in the region.
\end{abstract}

Keywords EU and NATO enlargement - Russia - Rule of law • Transitional justice $\cdot$ Corruption $\cdot$ State capture

Balkan peace and security has been a joint European and American enterprise since the NATO intervention in Bosnia in 1995. Though often at odds on specific issues, Americans and Europeans have worked in tandem on Dayton implementation, conflict prevention and resolution in Macedonia, the failed negotiations at Rambouillet, democratization in Serbia, and state-building in Kosovo. While the United States has often

(C) The Author(s) 2019

D. Serwer, From War to Peace in the Balkans, the Middle East and Ukraine, Palgrave Critical Studies in Post-Conflict Recovery, https://doi.org/10.1007/978-3-030-02173-3_6 
taken the military and diplomatic lead, Europe has just as often paid the lion's share of the bills and provided most of the military and civilian personnel. Experience suggests that when Brussels and Washington act in tandem, the odds of success are high.

This cooperation is now based on a common understanding that the countries of the Balkans belong in European and Euro-Atlantic institutions, including NATO if they want to join. That has meant they should all be democratic states with market economies governed under the rule of law. This is an ambitious work in progress, under difficult conditions. Progress is slow but palpable. Bulgaria and Romania, untouched by war in the 1990s, entered NATO in 2004 and the EU in 2007. Croatia and Albania joined NATO in 2009. Croatia joined the EU in 2013. Montenegro joined NATO in 2017. Macedonia is ready for NATO membership once the name issue with Greece is resolved. Montenegro and Serbia are trying to qualify for EU membership by 2023, which is necessary to accede in 2025 , after two years required for ratifications by the member states. This is a record of success, not failure, even if the process is slower than many might like.

There is one sense in which the Balkans are already imbued with the EU. The euro is either used in circulation or as a peg by all the countries of former Yugoslavia except Serbia. The benighted currency that many blame for Europe's current malaise has great virtue in the Balkans. Use of the euro has removed inflation and budgetary licentiousness as options for Balkan politicians. They have no option to devalue and no seigniorage (profits from producing currency), as they cannot print or mint euros. The result is an unexpected level of financial virtue in a region unlikely to develop it organically, as well as a reduction in frictional costs associated with currency exchange.

Good as it may be from those perspectives, the euro's problems and the lengthy European recession (lasting from 2008 to 2013), followed by slow growth, depressed not only Balkan economies but also spirits. Even today, many observers see little more than doom and gloom in the Balkans. ${ }^{1}$ Some think the post-Yugoslav peace settlements are on the verge of unraveling and would like to redraw borders along ethnic lines, imagining that could somehow be done without war. ${ }^{2}$ It is common today for people who live in the Balkans to suggest that they were better off under Tito in Socialist Yugoslavia, an allegation that neither honest memory nor per capita GDP figures support. Growth has been slower since the 1990s wars than prior to them, and both growth and 
institutional reform have lagged the pace the Baltics and Eastern Europe set after 1989. ${ }^{3}$ The per capita GDP gap with more developed countries is not narrowing. But all the former Yugoslav republics and Kosovo have seen substantial gains in per capita GDP, without counting their still substantial gray-market economies. Except in Kosovo, the "misery index" (unemployment plus inflation) improved throughout former Yugoslavia until 2010, when the global financial crisis hit the region hard. ${ }^{4}$ Looking forward, the World Bank sees resilient growth in the Balkans as well as improvement in employment and poverty reduction, albeit with rising risks. ${ }^{5}$

The temporary exigencies of the business cycle should not, however, distract from the region's long-run prospects. Can the Balkans ever really be part of the West? Will the region's war-torn and still troubled states abide by European values, enjoy European standards of living, and contribute to European peace and security? Can the countries that want to do so manage to equip themselves to join NATO and the EU?

The answers are not only up to those who live in and lead the Balkan states. Europe is suffering a crisis of confidence, enlargement fatigue, and nativist resurgence, brought on by recession, financial instability precipitated by the Greek debt crisis, the less-than-stellar post-accession performance of Bulgaria and Romania in implementing the rule of law, and waves of migration from North Africa and the Middle East, flowing in part through the Balkans. The UK's Brexit referendum in June 2016 cast a pall of doubt over Balkan EU aspirations. Poland and Hungary, which after the Berlin Wall fell were paradigms of liberal democratic transformation, are displaying troubling populist and authoritarian tendencies, as is Croatia. ${ }^{6}$ Even the territorial integrity of some existing EU members is in question: the independence aspirations of Scotland and Catalonia have made several EU countries nervous and less friendly than ever to Kosovo.

More broadly, the West is no longer the solid pillar of liberal democratic aspirations that it once was. President Trump has questioned NATO's mutual defense commitment, especially to Montenegro, casting doubts on the Alliance's usefulness and durability. American "national security" tariffs on steel and aluminum as well as the unilateral withdrawal from the Iran nuclear deal have offended Europe, Canada, and Japan. President Trump has also said he regards Europe as an economic foe and appears unaware of the partnership with Europe that has been at least partly successful in the Balkans. Ethnic nationalism is no longer only a Balkans syndrome: it is apparent throughout the EU and in the United 
States. The "West" as a liberal democratic construct is in peril as Russia takes advantage of opportunities to rattle its foundations while rapidly growing China rises as a strategic competitor.

Is it realistic to imagine that the door to the West really will open? Or that the West will remain a bastion of democracy? Has EU enlargement fatigue become enlargement exhaustion? Can the United States and the EU maintain their tandem efforts in the Balkans even as tension grows between Brussels and Washington? Will the remaining non-EU Balkan countries end up like Turkey, a NATO member but an eternal aspirant on the EU's periphery, sliding toward autocracy? Or will they not even get into NATO but remain on the periphery of both the EU and the Alliance?

Russia is now a key negative factor in the Euro-Atlantic ambitions of some Balkan countries. Orthodox Slavs in the Balkans have cultural, linguistic, religious, and historical ties to Russia. More religious and nationalist Serbs (in Serbia, Bosnia, and Montenegro) as well as some Macedonians feel the strong pull of Orthodox solidarity. Serbs have not forgotten the NATO bombings suffered during the Bosnia and Kosovo Wars. While Yeltsin's Russia in the 1990s was preoccupied with its own problems and unable to project image or power even as far as the Balkans, Putin's Russia is intervening militarily in Ukraine and Syria and is supplying major weapons systems to Serbia as well as equipment and training to Serb police in both Serbia and Bosnia. Putin's dominance in his July 2018 public appearance with President Trump in Helsinki will reinforce for some in the Balkans the idea that liberal democracy is fading while ethnic nationalism and Slavic solidarity are rising.

Moscow is doing what it can to exploit its pan-Slavic hard and soft power in the Balkans, with the objective of preventing NATO membership for Macedonia in the near term and eventually for Bosnia and Serbia. ${ }^{7}$ The means are many. ${ }^{8}$ Russian energy supplies, loans, organized crime, cyberattacks, and cultural and religious connections all serve the Kremlin's purposes. ${ }^{9}$ Moscow promotes demonstrations against NATO, talks up Russia's role in the world and downplays NATO's, invites lots of Slav officials and politicians to visit, conducts military exercises with Serbia, and has established a "humanitarian" logistics base there. Russian companies have invested in Serbia, Montenegro, and the Republika Srpska part of Bosnia. ${ }^{10}$ Russia Today and Sputnik News feed the Balkans media nationalist and anti-Western stories. 
These anti-NATO efforts have strengthened significantly in recent years. ${ }^{11}$ Most notably, in October 2016, Moscow campaigned against Montenegro's pro-NATO prime minister, supplying funds and organization to his principal opponent, and set in motion a coup plot to enable pro-Russian politicians there to seize power in the event they lost the election. Only the cooperation of Serbia's prime minister and quick action by the Montenegrin security services prevented the Russian-linked plotters from killing Prime Minister Đukanović. ${ }^{12}$ The United States' November 2016 election was not the only one President Putin tried to disrupt.

Will Macedonia be prepared to buck Russia's growing opposition to NATO membership, as Montenegro has? Will Bosnia achieve the kind of cross-ethnic consensus to allow it to ask for a NATO Membership Action Plan? Will Serbia, Bosnia, Macedonia, and Kosovo be able and willing to institute the political and economic reforms needed for EU accession?

The idea of all the Balkans countries eventually joining the EU and NATO is a recent and daring one. Europe in the 1990s was still thinking of the Balkans countries as a neighborhood issue, not membership possibilities. NATO regarded the Balkans as "out of area" until it intervened in Bosnia in 1995. While individuals may have imagined such a development earlier, and Slovenia was already well on its way soon after independence in 1991, the origin of the idea of a Euro-Atlantic destination for all the Balkans can be traced to the Sarajevo Summit of 1999, which launched an initiative called the Stability Pact. It sought to engage the region in mutually beneficial efforts of many different sorts, from human rights to free trade and from energy supply to fighting organized crime. ${ }^{13}$

Whatever the merits of the specific projects undertaken by the Stability Pact, which today has been transformed into a Regional Cooperation Council focused mainly on infrastructure, jobs, and other economic issues, it represented the dawn of one big idea: those Balkan countries that want to do so could prepare for and hope to enter the EU, other European organizations like the Council of Europe and the European Investment Bank, as well as NATO. This idea was codified at the 2003 Thessaloniki EU Summit: "The EU reiterates its unequivocal support to the European perspective of the Western Balkan countries. The future of the Balkans is within the European Union." 14 This teleological postulate is extraordinary. Just eight years after the war in Bosnia, just four after the war in Kosovo, and just three after the fall of Milošević, the EU declared its willingness to accept all the countries of the Western 
Balkans as members, if they qualify. Those eligible for EU membership are normally regarded as eligible also for NATO membership. No one should minimize this development, which gave at least some in the Balkans a clear sense of direction and purpose during the first decade of this century.

NATO membership has proven easier and quicker to qualify for than EU membership, though delays in accession are still common. Slovenia, Croatia, and Albania are already NATO members. Montenegro failed to get in at the Wales Summit in 2014 mainly because the Alliance did not want to take the risk of provoking an already overwrought Russia, which had invaded Ukraine, for an infinitesimal gain in Alliance military capability. Rebuffing Moscow's entreaties, inducements, and threats, Podgorica received an invitation at the NATO Summit in Warsaw in 2016 and formally entered in 2017. Macedonia is now fully qualified. It got an invitation to join NATO in July 2018, with accession likely a year later, provided the name issue is resolved.

For now, Belgrade is not seeking NATO membership, but it has joined Partnership for Peace, the NATO anteroom for non-members, and frequently joins NATO exercises and training activities. Russia, however, will work hard in Serbia against NATO, as it did in Montenegro. Putin's annexation of Crimea and invasion of eastern Ukraine have revived the hopes of some in Belgrade that Serbia might be able to achieve something similar in Kosovo, annexing or at least de facto controlling the Serb-majority territory in the north. Some also harbor hopes of Republika Srpska seceding from Bosnia. If those are your objectives, you would lean over backwards to befriend Moscow.

Kosovo has a wide social consensus in favor of NATO membership among the Albanians, but it lacks an army. Its lightly armed security forces focus on emergency relief and leave the defense of its territory mostly to KFOR. The Americans and Europeans are insisting that Pristina make a concerted effort to gain Kosovo Serb approval for its creation, but that is proving impossible due to Belgrade's opposition. Kosovo will build its armed forces to NATO standards from the start, likely relying on legislation rather than a constitutional amendment. ${ }^{15}$ So long as Pristina can ensure that its neighbors do not get nervous about its capabilities, the route to NATO's Partnership for Peace could be blessedly short. The only real obstacle to membership is the presence inside the Alliance of four members that do not yet recognize Kosovo: Spain, Greece, Romania, and Slovakia. 
Kosovo will need a security force able to counter a Serbian invasion for at least a week or ten days, as well as an ironclad agreement with NATO for help should Serbia move to retake any part of Kosovo's territory. You only need watch what Russia has done in Ukraine, Georgia, and Moldova, or remember what Serb forces did in Croatia, Bosnia, and Kosovo in the 1990s, to recognize how important it is to be able to protect the borders of a state that claims to be sovereign. By the same token, Serbian recognition and exchange of ambassadors would alleviate the threat and allow Kosovo to build less potent forces more adapted to international deployments, which are a main activity for the Croatian, Albanian, Montenegrin, and Macedonian armed forces because there is no serious remaining threat at home.

Bosnia is divided on NATO, as it is on many things. Its Serb leadership shows little interest in the Alliance, which contributed mightily to the defeat of Republika Srpska's army at the end of the war in 1995 and helped force the unification of Bosnia's three armies a decade later. The Alliance wants issues arising from the division of military property in Bosnia resolved before it will give Bosnia a plan for achieving membership. But entering NATO, like EU membership, would mean a strengthened central government in Sarajevo, which would displease Republika Srpska's President Dodik as well as the country's more nationalist Croat leadership. It is therefore convenient for them to hold tough on the defense property issues, as they have for years. Today's small Bosnian Army might readily meet NATO standards, as it has worked closely with the Alliance for more than ten years. Bosnia's Muslims and many of its secularists would welcome NATO membership, but it would require nationalist Serb and Croat political support that for now is lacking.

EU membership is far more difficult than NATO membership and takes much longer. Why? All aspirants for EU membership need to be able to implement the acquis communautaire, the body of law and regulation that enables an EU member to be an EU member. There is no way to summarize its now thirty-five chapters. Standing on a street corner in Rome, the acquis surrounds you: it requires the newly made curb cuts, it determines the shape, size, and graphics on the street signs, it dictates the sanitary standards in the restaurants and markets as well as the fiduciary requirements for the banks. 
In addition to these technical standards, Balkan countries need to undertake the political and economic reforms required for them to qualify, a bar that rises with every new enlargement. For the states emerging from former Yugoslavia, the transformation is a multi-faceted one: from state-centered socialism to free-market capitalism, from autocracy to liberal democracy, from war to peace, from ethnic nationalism that privileges one group over others to respect for minorities and individual human rights, and from corrupt cronyism to transparent and accountable governance. However attractive in theory, such transformations threaten domestic elites and traditional patronage networks, which resist. The EU uses conditionality to try to overcome such resistance. Financing, technical assistance, and infrastructure investments depend on progress in meeting EU requirements. But that effort is a complex and difficult one whose impact depends on the domestic conditions in each prospective member, including most notably the degree to which the state is well established and uncontested both internally and externally. ${ }^{16}$ The history of the former Yugoslav states since 2003 revolves in large part around the successes and failures of this effort to build states that can qualify for EU membership, which is still far from completed.

The contrast with the previous decade is striking. In 1991 the Luxembourgeois politician Jacques Poos had declared that "the hour of Europe has dawned" on his way to the negotiation that ended the war in Slovenia. He meant that Europe would peacefully end war in the Balkans, not that the Balkans would ever join Europe. That statement was the object of derision for years in the State Department as Europe's persistent but futile efforts to bring the Balkan wars to a close failed miserably in Croatia, Bosnia, and Kosovo. American diplomats often referred to the Europeans laughingly with the f-word: feckless. Today, however, Washington sees EU and NATO membership for those Balkan countries that qualify as a serious, even indispensable objective, not least because it at least partially relieves Washington of what might otherwise be a burden. Washington has tried to pass leadership in the Balkans to the EU. ${ }^{17}$

The EU's willingness to open its doors to the Western Balkans has had an extraordinary impact in those countries most able to take advantage of the opportunity. Slovenia entered the EU in 2004. Croatia in the first decade of this century made a concerted effort to prepare itself for EU membership, and in 2013 it succeeded. Montenegro and Serbia are now leading the regatta for EU membership and show substantial signs 
of getting serious about efforts to qualify. The EU invented a "high-level dialogue" for Macedonia that was intended to substitute for the accession negotiations Greece would not allow, but that bureaucratic exercise failed to convince Macedonia's citizens and leadership that EU membership was a realistic objective. It is hard to maintain political momentum to adopt often burdensome EU requirements when candidacy appears unattainable. But Albania and Macedonia are now slated to start negotiations before the end of 2019, provided the former meets EU demands concerning corruption and rule of law and the latter succeeds in its effort to resolve the name issue with Greece. The lessons learned in the premature 2007 accessions of Bulgaria and Romania are being applied. ${ }^{18}$

Serbia formally started EU accession negotiations in January 2014. Belgrade got candidacy status and later the date for negotiations to begin not strictly on the traditional merits but rather as a reward for progress in normalization of relations with Pristina, consummated in the April 2013 Brussels Agreement that provided for reintegration of the northern Serbmajority municipalities with the rest of Kosovo. Many in Washington and Brussels felt that it was more important to get Serbia into the process than to insist on all the preconditions, which reduce the attractiveness and immediacy of EU membership and thereby diminish the incentives for reform. In December 2015, Serbia opened Chapter 35, which includes normalization of relations with Kosovo, and Chapter 32, on financial controls.

Belgrade is certainly serious about the EU but is still not fully aligned with it, especially in foreign policy. President Vučić has deemphasized holding on to all of Kosovo, without, however, promising bilateral recognition. Though he knows it, he does not publicly acknowledge that EU members that have recognized Kosovo will not accept Serbia as a member if it continues to claim sovereignty. Serbia remains at odds with the EU over press freedom and has refused to align its positions with Brussels on Ukraine, sanctions on Russia, and the (now cancelled) Putin-sponsored South Stream natural gas pipeline. Some in Serbia pride themselves even after the end of the Cold War on leadership in the NonAligned Movement. The EU knows a great deal about dealing with issues of this sort. Sweden, Finland, and Austria all saw themselves as "neutral" during their accession to the EU, but that occurred in 1993 at a much less contentious time in relations between the West and Moscow. Serbia's reluctance to defy Moscow could slow the accession process, 
assuming current tensions between the EU and Russia over Ukraine continue. ${ }^{19}$

The two remaining laggards in joining the EU are Bosnia and Kosovo. In Kosovo, both elite and grassroots verbal support for EU membership is strong. All its legislation is required to be consistent with EU standards, although implementation often lags shamefully. ${ }^{20}$ Also important is that Europe is divided on Kosovo's independence, with five EU members not yet recognizing Kosovo. This split renders the EU less than enthusiastic about making Kosovo a candidate and opening an accession negotiation with Pristina. Kosovo's leadership doubts that the EU can deliver on membership, but Kosovo signed a Stabilization and Association Agreement with the EU in 2015 and has qualified for a visa waiver program, which all other Balkan countries already have.

In Bosnia, elite support for EU membership is weak and grassroots interest is flagging. Its politicians appear to be suffering the "Sanader effect." Several no doubt fear that the more independent judiciary and stronger anti-corruption efforts the EU requires would land them in jail. Getting into the visa waiver program for Europe's Schengen Area did mobilize Sarajevo to quick action to meet European passport standards, but in general Bosnia has lagged in meeting European requirements. The British and Germans initiated in 2014 an effort to do for Sarajevo what was done for Belgrade: give it an easy ticket to candidacy status, provided the Bosnians adopt minimal reforms to the country's labor laws in preparation for privatization. The Europeans think this will reduce corruption, make the carrot of EU membership more imminently attractive, and allow the European Commission to wield the stick more forcefully during the accession negotiations rather than in anticipation of them. This approach would cost Europe some credibility in the short term, but those who advocate it think it will increase the pressure on Balkans politicians to ignore the Sanader effect and run the risks associated with the EU accession process. So far, it has not worked. ${ }^{21}$ Bosnia submitted a membership application to the EU in 2016 and managed to respond to the EU's questionnaire about its qualifications by early 2018 , but its answers demonstrated all too clearly that it still lacks the internal cohesion and state capacity required to make a serious run at accession. ${ }^{22}$

It has been argued that Europe's transformational power has met its match in postwar Balkan environments, especially in Bosnia and Kosovo. ${ }^{23}$ Certainly no one would argue that their accession is inevitable, despite the decades that have passed since their conflicts. Backsliding 
happens, due principally to weak institutions and authoritarian political bosses. ${ }^{24}$ Nor, however, is it clear that their transformations are destined for ultimate failure. In Bosnia the problem is nationalist leadership that relies on the current constitutional framework to ensure their hold on power. They have no need to deliver political or economic reform to satisfy their ethnically defined constituencies. A trans-ethnic challenge could, however, be mounted, either at the ballot box or in the streets, especially if it finds support in both Brussels and Washington. If that happens, Bosnia could advance quickly toward both NATO and the EU, as happened in Macedonia after the fall of Gruevski. In Kosovo the main diplomatic issue is incomplete sovereignty, which could be resolved in negotiations Brussels reinitiated in July 2018. Kosovo need not remain a case of contested statehood, and it will not if Belgrade gets serious about EU membership, which will require recognition and establishment of diplomatic relations with its former province. The dire consequences of allowing Kosovo's status to remain unresolved are all too foreseeable. ${ }^{25}$

For both Bosnia and Kosovo, divisions within the West are a large part of what makes EU and NATO accession so difficult and their "transformational" impact so dilute. Closing those divisions would go a long way toward increasing the incentive of Sarajevo and Pristina to hasten reforms. In Bosnia, what is needed is for the United States and the EU to agree on minimal constitutional reforms that would enable all citizens to be candidates for the presidency and empower the Sarajevo government with the authority it needs to negotiate and implement the acquis communautaire. In Kosovo, what is needed is for the five EU members who do not recognize Kosovo's sovereignty (Cyprus, Greece, Romania, Slovakia, and Spain) to commit to doing so once it qualifies for EU candidacy. Even if two or three would do so, the effect would be significant. Greece-once it has settled the name issue with Macedonia-Romania, and Slovakia have no strong basis on which to continue to deny recognition. Spain and Cyprus do so for fear it might encourage the independence ambitions of Catalonia and Northern Cyprus. That is specious, unless they regard their own governments as the moral equivalent of Milošević's Serbia.

Perhaps the most difficult part of qualifying for EU membership is respect for individual human rights, which is at the core of what defines liberal democratic regimes. Nowhere in the territory that once belonged to Yugoslavia is commitment to human rights at truly European levels, though Slovenia comes closest. The other former Yugoslav states have all 
gone through a process of denial of human rights violations, lip service to human rights norms, tactical concessions on relatively minor issues like display of flags, as well as avowed and legislated but often still hollow commitment to meeting EU standards. While many observers bemoan the lack of sincerity, this happens to correspond to the "spiral model" of adaptation of autocracies to international human rights norms. ${ }^{26}$ None of the former Yugoslav states have entirely internalized them or complied in detail with their requirements, largely because there is little domestic constituency insisting that they do so, except among abused minorities. The committed and energetic civil society organizations that advocate for human rights throughout the Balkans have limited mass appeal. Nor have any of the former Yugoslav states become serious promoters of human rights norms internationally, except when applied to their co-ethnics across the border (Serbs in Croatia, for example, or Bosniaks in Serbia). Those are future stages of the "spiral model," which will require another decade or more.

One of the key barriers to completing this process of adaptation to human rights norms is accountability for past atrocities, known these days as "transitional justice." There are still individuals, ideologies, and institutions in the Balkans associated with wartime abuses. Bosnia's Republika Srpska was originally founded to create a Serb-dominated area cleansed of Croats and Bosniaks that would eventually unify with Serbia. The winning political party in Croatia's 2016 parliamentary election played an important role in trying to create a Croat entity in Bosnia during the Bosniak/Croat war and in advocating ethnic cleansing of Serbs in 1995. Two of Kosovo's main political parties (and its current president and prime minister) trace their origins to the Kosovo Liberation Army, which committed abuses against both Serbs and Albanians during and after the 1999 war. Serbia's president and foreign minister were associated with the Milošević regime in the 1990s.

We are still a long way from the sincere mutual acknowledgment of harm that is known to enable a spiral of genuine reconciliation. ${ }^{27}$ The International Criminal Court for the former Yugoslavia captured all and tried most of its 161 indictees, including major wartime leaders, and domestic courts have prosecuted lower-level perpetrators, especially in Serbia and Bosnia. The removal of high-level indicted war criminals from their home countries was vital. Had they remained, either free or under arrest, they would have made governance and democratization even harder than it has been. ${ }^{28}$ But many indictees are still regarded as heroes 
in their home countries. Acquittals of co-nationals are greeted with joy and convictions with resentment. Apologies often ring hollow. Higherlevel indictments in domestic courts lag, and none of the trials has had a truly transformative effect on public opinion or domestic norms. ${ }^{29}$ A grassroots civil society campaign for a regional truth and reconciliation commission has not yet been successful. ${ }^{30}$ Especially in Serbia, whose wartime leader was so instrumental to the wars of Yugoslav succession, the outcome so far is a shifting discourse on guilt, responsibility, and denial that is at best partial, ambiguous, or both. ${ }^{31}$

The hardest part of qualifying for both the EU and NATO is rule of law, which appears in several of the chapters (especially 23 and 24) and is an indispensable foundation for the whole. The all too obvious failure of EU members Romania and Bulgaria to meet European rule-of-law standards before accession caused Brussels to stiffen its requirements and initiate negotiation of rule-of-law issues early in the process, since they take a long time to resolve. Accession for Slovenia and Croatia was challenging, but the remaining non-member Balkans countries will face a still harder road.

This is a good thing, not a bad one. Serbia, Montenegro, Albania, Kosovo, Macedonia, and Bosnia will all have problems meeting European rule-of-law standards, but doing so will benefit each of them immensely. Foreign and domestic investors, as well as ordinary citizens, want to know that they will be treated fairly, which requires a capable and transparent system of laws and courts. They also want to know their money and property will not be stolen.

The two biggest rule-of-law issues throughout the Balkans are corruption and inter-ethnic crime. Both require not only good laws on the books but also good implementation. Corruption in the United States is generally defined as the abuse of public office for private gain. The opposite of corruption is not anti-corruption. It is good governance: the use of public office for public gain. That depends not only on good laws, good courts, and a good anti-corruption agency but also on social norms, free media, political competition, independent regulatory institutions, and vigorous civil society.

Balkan governments pass good laws and create anti-corruption agencies. What they lack are the other elements. This puts most Balkan countries around the second quartile of the global 2017 Transparency International Corruptions Perceptions rankings. ${ }^{32}$ This is not good, though Romania, Bulgaria, and Greece-already EU members-are 
in this range as well. No one in the Balkans is immune. Corruption is a regional problem, derived in part from wartime smuggling and sanctions-busting on all sides as well as persistent family connections that make nepotism in hiring not only common but expected. Low publicsector salaries, overly powerful political parties, and weak professionalism among government workers contribute as well. The Communist states in the Balkans may have looked strong before the fall of the Berlin Wall, but in fact they were fragile and all too often incompetent. Autocracy betokened weakness, not strength.

What does this mean for the region's citizens? Close to $10 \%$ of Kosovo's population pays bribes every year. ${ }^{33}$ That might not sound like a lot, but if we assume it has been going on since independence and it is not always the same people paying bribes, most of the population has paid a bribe, and the others will have heard about it and likely soon do it. That creates a culture of impunity. Corruption is not only about the trash collector, the building permit, and the business license. Some highlevel malfeasance is invisible. But there is also malfeasance that is apparent in the way people live, entertain, and behave. If government officials are living beyond their means, consorting with known criminals or hiring their relatives, it is usually no big secret. What is needed are courageous journalists who will write about it, newspapers that will publish it, civil society organizations that will campaign against it, and voters who will cast their ballots with it in mind. And then prosecutors and judges who will investigate, prosecute, and convict.

One form of corruption much discussed throughout the Balkans is state capture. This refers to a situation in which private interests control and exploit governments. The implicit comparison is often with fully consolidated democracies, or even with some ideal paragon of democracy. ${ }^{34}$ By comparison, the Balkans is highly dependent on political party bosses and their patronage networks, some of which have entrenched themselves for decades. Their clientelist networks know well how to resist, and adapt to, whatever the EU tries to impose. Partitocracy limits the EU's transformative power, enabling formal compliance while blocking serious reform and allowing corrupt practices to continue. ${ }^{35}$ Not surprisingly, this is especially the case where domestic accountabilitythrough either autonomous government institutions or civil society-is lacking. ${ }^{36}$

State capture is often blamed on foreigners, especially on the United States and the EU, who are said to prefer a promise of stability even if it 
means maintaining corrupt leaders in power. The neologism is "stabilitocracy": "Governments that claim to secure stability, pretend to espouse EU integration and rely on informal, clientelist structures, control of the media, and the regular production of crises to undermine democracy and the rule of law." ${ }^{37}$ In return for the pretense of stability, the EU is said to pretend to keep the doors open to membership. The implication is that everyone is happy to slow EU accession. There is one clear case: Bosnia, where the EU has purposefully avoided constitutional reforms (over the objections of the United States) that it fears might destabilize the peace settlement. Even in that instance, however, the Russian role in guaranteeing support to Republika Srpska is a key factor that inhibits a forceful effort by the Americans and Europeans. Why try something that is not going to work?

Otherwise, there is little evidence of Western support for such governance, provided there is a viable alternative. In Macedonia, the United States and the EU were prepared to pry the state loose from Prime Minister Gruevski's tight hold, once protesters signaled overwhelming citizen disapproval and electoral results opened up the possibility of a reform-minded democratic alternative. In Albania and Kosovo, the EU and the United States have invested heavily in trying to create independent judiciaries, without much success. Autonomous institutions and civil society there are still weak, but no one in Washington or Brussels is going to be too upset if the judiciaries start indicting current leaders based on real evidence. The constitutional court in Kosovo has intervened more than once to nullify presidential elections, with international backing. There was some regret but little hesitation when Kosovo Prime Minister Hardinaj was shipped to The Hague in 2005. In Montenegro there is still no remotely acceptable alternative to Đukanović, who wins elections without controlling the media against an opposition that opposes the country's independence. By contrast, in Serbia Vučić's media dominance is complete and his opposition too fragmented and weak to present a serious alternative. Concern about "stabilitocracy" supported by Brussels and Washington may not reflect so much the situation in the Balkans as it does European and American dissatisfaction with election results, which often return nationalist heroes and would-be autocrats rather than committed reformers. The disappointment is understandable but ill behooves those advocating democracy.

The people best placed to undo state capture are not the foreigners but a country's own citizens. The problem is arguably that 
anti-corruption campaigns do not bring electoral success but instead delegitimize elites and destabilize the political system. Citizens do not perceive the corresponding benefits. ${ }^{38}$ Foreign governments can and should weigh in to sanction corrupt individuals and human rights violators, using tools like the U.S. Global Magnitsky Act. ${ }^{39}$ The EU and its member states have been far too shy about following the U.S. lead in this respect, in part for fear of judicial challenges. But no foreigner knows the Balkans better than the people who live there. It was Italian magistrates like Giovanni Falcone who beat the Sicilian mafia, which murdered him on its way to defeat. Only Italians could do it, though the Americans helped with intelligence and witness protection. It will be courageous Kosovars, Serbs, Bosnians, and Montenegrins who uproot corruption, both at the retail and leadership levels. The EU could certainly help more than it currently does with intelligence, witness protection, and targeted sanctions, but there is no foreign substitute for local courage and conviction.

The same is true of inter-ethnic crime. This has also been much discussed in Kosovo, as the weaknesses of the Kosovo judicial system inspired the internationals to demand a "special court" to try war crimes cases against leaders of the KLA (involving murders of Albanians as well as Serbs and possibly others). The new tribunal is a Kosovo court with international judges and prosecutors convening in The Hague. There is nothing terrible about this proposition. If a Scottish court can convene in The Hague to try the Libyan Pan Am 103 bombers, why can't a Kosovo court? Kosovars, Serbs, and others have been tried by international prosecutors and judges at the International Criminal Tribunal for former Yugoslavia. A Kosovo court with international staff is not an unreasonable proposition to establish accountability and provide a modicum of justice.

"Why us?" people in the Balkans always ask. Other Balkan countries have not been asked to do this, that, or the other thing. Kosovo was asked to establish a special court outside the country because the internationals do not have confidence in the Kosovo courts, not even as much confidence as they have in the Bosnian, Macedonian, and Serbian courts, all of which have made some progress in handling inter-ethnic crime. This should be a source of embarrassment, and inspiration. Enabling the Kosovo courts to deal effectively with inter-ethnic crime should be the goal of anyone wanting Kosovo to be fully sovereign, which is what is required before it can become a EU member. 
In addition to corruption and inter-ethnic crime, a third rule-of-law issue threatens to lengthen the process of preparing Bosnia and Kosovo for NATO and EU membership: the recruitment of Islamic State fighters in their generally moderate Muslim populations. The absolute numbers are small: a few hundred fighters from Kosovo, and fewer than that from Bosnia. But relative to population the proportions are high, the highest per capita in Europe ${ }^{40}$ There is no doubt about the willingness of the dominant political parties in both countries to take action-their politicians feel the threat of the Islamic State as strongly as the United States or Europe does. Laws have been passed, but like so much legislation in the Balkans it has proven difficult to implement effectively, and no one has yet figured out what to do with returning foreign fighters.

Improvement in inter-ethnic relations, establishment of rule of law, and blocking recruitment of foreign fighters requires something else that the Balkans still lacks, more than twenty-five years after the fall of the Berlin Wall: economic reform. Throughout the Balkans, people of all ethnicities tell the joke about a farmer (usually of another ethnicity than the storyteller) who finds a magic lantern. When he rubs it and the genie emerges, the farmer's first wish is that his neighbor's cow should die. "What good will that do you?" the genie asks. "None," says the farmer, "but it will make him very unhappy." Sad to say, people in the Balkans laugh at this joke, while admitting it reflects a zero-sum mentality common among all the ethnic groups.

Everyone assumes that a bigger slice means less for someone else. No one has confidence that the pie can be made to grow. Politicians therefore look for international support wherever they can get it: witness opaque loans from Russia to Republika Srpska. ${ }^{41}$ Ethnic tension and fat loans help ethnic nationalists stay in power. So too do state-owned companies, which provide patronage and corruption opportunities. One of the keys to further progress throughout the Western Balkans is internationally supervised, transparent privatization.

Renewed economic growth would open new opportunities for youth, ease ethnic tensions, strengthen pro-European political forces, and allow everyone to enjoy his neighbor's prosperity. This is where enterprises like the Regional Cooperation Council, the European Investment Bank, and the European Bank for Reconstruction and Development really count. Goran Svilanović, who as foreign minister happens to have been one of the first Serbian officials to acknowledge that Kosovo was lost, now heads the Regional Cooperation Council, the Balkans-owned heir of the 
Stability Pact. Its 2020 South East Europe Strategy, "Jobs and Prosperity in a European Perspective," is precisely what the region needs: its targets are increased trade and investment, growth and jobs, business creation, and improved governance. ${ }^{42}$

Infrastructure is the heart of matter. The road from Durres (Albania) to Pristina is one of the few major improvements in the Balkans transportation infrastructure in the past twenty years. Kosovo spent a great deal of money on it, but it has had no serious positive economic impact. Extension of the road to Nis (in Serbia) would greatly increase its benefits, but of course that is still difficult given rocky Serb/Kosovar relations. That is the kind of effort worth thinking about and working toward in a regional context: it would both make the initial investment worthwhile and could improve inter-ethnic relations.

Vesna Pusić, once Croatia's foreign minister, summarized the first two decades of Croatian independence as moving from heroic to boring politics. Even in Croatia that is not entirely true, as vigorous nationalists have since returned to power there. In Serbia, Bosnia, and Kosovo they have hardly ever left power. There was a heroic moment after the Berlin Wall fell when the most important objectives in fragmented Yugoslavia were the realization of national ambitions, self-determination, and assertion and recognition of national identities and boundaries. Tuđman, Milošević, Izetbegović, Gligorov, and Rugova were the respective national heroes. The better part of their aspirations is fulfilled. Now it is time for the mundane, which Pusić called "boring." Boring and rewarding. The Balkans is no longer at war. Individuals in specific places and times may be at risk, which is true in Washington as well as in Mitrovica/ Mitrovicë. But no group has reason to fear mass atrocity, and most individuals have no good reason to fear persecution.

Once-oppressed peoples are now majorities or pluralities who should worry less about themselves and more about the minorities who live among them. It will be far easier to meet obligations in that respect in a prosperous environment than in a stagnant one. The Regional Cooperation Council has set reasonable objectives. Meeting them will generate the resources and time needed to work on the far more difficult rule-of-law criteria for EU membership.

The bridge between today and the future of the Balkans in NATO and the EU is paved not with heroism but with political moderation and economic prosperity. Washington and Brussels need to work together to keep the Balkans moving in the right direction, allying with Balkan 
citizens whenever possible. When they do, no one resists for long. Each Balkan country will need to find its own path. But the vanguard experience of Slovenia, Croatia, Montenegro, and Macedonia points unequivocally in the right direction, even if hesitation and backsliding are frequent. Enlargement fatigue and concern about rule of law have slowed their progress from time to time, and there is never a guarantee that when a country is ready for EU or NATO membership the internal politics of those organizations will align in a way to permit accession. But none of the current or potential Balkan candidates represents more than a tiny fraction of the EU's more than 500 million people ( 440 million even without the UK). Admitting Bosnia (less than 4 million) or Kosovo (less than 2 million) is not like admitting Turkey's 75 million plus. The trick for each of the Balkans countries is to get ready and wait for the political door to open, which it does from time to time.

If they want, the remaining problem countries of the BalkansMacedonia, Serbia, Kosovo, and Bosnia-will someday become NATO and EU members. They will also be friends of the United States and leaders in helping the rest of the world find peace and prosperity. That will be a worthy conclusion to more than two decades of intervention. Even opening that possibility has made the effort worthwhile.

\section{Notes}

1. For a well-crafted example, see Jasmin Mujanovic, Hunger and Fury: The Crisis of Democracy in the Balkans (Oxford: Oxford University Press, 2018).

2. Timothy Less, "Dysfunction in the Balkans: Can the Post-Yugoslav Settlement Survive?" Foreign Affairs, December 20, 2016, https:// www.foreignaffairs.com/articles/bosnia-herzegovina/2016-12-20/ dysfunction-balkans.

3. Oleh Havrylyshyn, Xiaofan Meng, and Marian L. Tupy, "25 Years of Reforms in Ex-communist Countries: Fast and Extensive Reforms Led to Higher Growth and More Political Freedom," CATO Institute, no. 795 (July 12, 2016), https://www.cato.org/publications/policy-analysis/25years-reforms-ex-communist-countries-fast-extensive-reforms-led.

4. Franjo Štiblar, "Economic Growth and Development in Post Yugoslav Countries," Wilson Center Global Europe Program, June 2013, https:// www.wilsoncenter.org/sites/default/files/Franjo_Stiblar_WWICS.docx.pdf.

5. World Bank Group, "Resilient Growth Amid Rising Risks," Southeast Europe Regular Economic Report no. 10 (Fall 2016), http://pubdocs.worldbank. org/en/521981474898709744/SEE-RER-Report-Fall-2016.pdf. 
6. Dalibor Rohac, “Hungary and Poland Aren't Democratic: They're Authoritarian," Foreign Policy, February 5, 2018, https://foreignpolicy. com/2018/02/05/hungary-and-poland-arent-democratic-theyre-authoritarian/.

7. Margarita Assenova, "Moscow Pushes to Derail Macedonia's NATO Membership," Eurasia Daily Monitor 15, no. 117 (August 6, 2018), https://jamestown.org/program/moscow-pushes-to-derail-macedoniasnato-membership/.

8. Mark Galeotti, "Do the Western Balkans Face a Coming Russian Storm?" (European Council on Foreign Relations Policy Brief), April 2018, https://www.ecfr.eu/publications/summary/do_the_western_balkans_ face_a_coming_russian_storm.

9. United States Senate Committee on Foreign Relations, "Putin's Assymetric Assault on Democracy in Russia and Europe: Implications for U.S. National Security," January 10, 2018, https://www.foreign.senate. gov/imo/media/doc/FinalRR.pdf.

10. Center for the Study of Democracy, "Assessing Russia's Economic Footprint in the Western Balkans" (Sofia, 2018), http://www.csd.bg/ artShow.php?id=18131.

11. "The Warp of Serbian Identity: Anti-Westernism, Russophilia, Traditionalism," Helsinki Committee for Human Rights in Serbia, Studies no. 17, http://www.helsinki.org.rs/doc/Studies17.pdf.

12. Daniel Serwer and Sinisa Vukovic, "This Is What It Looks Like When Russia Really Wants to Mess with Your Election," Foreign Policy, November 8, 2016, https://foreignpolicy.com/2016/11/08/this-iswhat-it-looks-like-when-russia-really-wants-to-mess-with-your-election/.

13. "Meeting for Regional Leaders on the Stability Pact, Sarajevo, July 29, 1999," Joint Office for South East Europe, May 1, 2009, http://www. tpk.fi/ahtisaari/puheet-1999/P990729.open.html.

14. "EU-Western Balkans Summit, Thessaloniki, 21 June 2003," European Commission, June 21, 2003, http://europa.eu/rapid/ press-release_PRES-03-163_en.htm.

15. Robert Muharremi, "Kosovo Security Force Is an Army: Legal Arguments," Kosovar Centre for Security Studies Policy Brief, March 2016, http://www.qkss.org/en/Policy-Papers/Kosovo-Security-Forceis-an-Army-Legal-Arguments-649.

16. Arolda Elbasani, European Integration and Transformation in the Western Balkans: Europeanization or Business as Usual? (New York: Routledge, 2013).

17. Daniel Serwer, "U.S. Policy on the Western Balkans," in Unfinished Business: The Western Balkans and the International Community, ed. Vedran Džihić and Daniel Hamilton (Washington, DC: Center for Transatlantic Relations, 2012), 221-29. 
18. Susie Alegre, Ivanka Ivanova, and Dana Denis-Smith, Safeguarding the Rule of Law in an Enlarged EU: The Cases of Bulgaria and Romania, CEPS Special Report/April 2009 (Center for European Policy Studies, 2009), https://www.ceps.eu/system/files/book/1833.pdf.

19. See, for example, "Lithuania Blocking Chapter Because of BelgradeMoscow Ties," B92, July 31, 2018, https://www.b92.net/eng/news/ politics.php?yyy $=2018 \& \mathrm{~mm}=07 \& \mathrm{dd}=31 \&$ nav_id $=104749$.

20. Andrea Lorenzo Capussela, State-Building in Kosovo: Democracy, Corruption and the EU in the Balkans (London: I. B. Tauris, 2015).

21. Bobo Weber, "Substantial Change on the Horizon? A Monitoring Report on the EU's New Bosnia and Herzegovina Initiative," Democratization Policy Council, March 2017, http://www.democratizationpolicy.org/ pdf/DPC_EU_BiH_Initiative_Monitoring_Report.pdf.

22. "Answers to the Questionnaire," Directorate for European Integration in Bosnia and Herzegovina, http://dei.gov.ba/dei/direkcija/sektor_ strategija/Upitnik/odgovoriupitnik/Archive.aspx?pageIndex=l\&lang Tag=en-US.

23. Marco Zambotti, "Questioning Europe's Transformative Power: The EU in Bosnia and Herzegovina, and Kosovo (1995-2015)," (PhD diss., Johns Hopkins University, 2015).

24. Forian Bieber, "Rethinking 'Democratic Backsliding' in Central and Eastern Europe," East European Politics 34 (2018): 337-54.

25. Friedrich Ebert Stiftung, "Serbia and Kosovo in 2035: Scenarios," Belgrade, March 2018, http://library.fes.de/pdf-files/bueros/belgrad/14369.pdf.

26. Thomas Risse, Stephen C. Ropp, and Kathryn Sikkink, The Persistent Power of Human Rights: From Commitment to Compliance (Cambridge: University Press, 2013).

27. Olga Botcharova, "Implementation of Track Two Diplomacy: Developing a Model of Forgiveness," in Forgiveness and Reconciliation: Religion, Public Policy, and Conflict Transformation, ed. Raymond G. Helmick and Rodney L. Petersen (Philadelphia: Templeton Press, 2002), 279-304.

28. Julian Borger, The Butcher's Trail: How the Search for Balkan War Criminals Became the World's Most Successful Manhunt (New York: Other Press, 2016).

29. Humanitarian Law Center, "Report on War Crimes Trials in Serbia during 2016," May 2017, http://www.hlc-rdc.org/wp-content/uploads/2017/ 05/Izvestaj_o_sudjenjima_za_2016_eng.pdf; "Second Report on the Implementation of the National Strategy for the Prosecution of War Crimes," June 2018, http://www.hlc-rdc.org/wp-content/uploads/2018/ 07/Izvestaj_Strategija_2_ENG-ff.pdf.

30. "RECOM Roadmap Policy Brief," Recom, May 2018, http://recom. link/wp-content/uploads/2018/06/RECOM-Roadmap-ff-1.pdf. 
31. Eric Gordy, Guilt, Responsibility, and Denial: The Past at Stake in PostMilosevic Serbia (Philadelphia: University of Pennsylvania Press, 2013).

32. "2017 Corruption Perceptions Index," Transparency International, February 2018, https://www.transparency.org/news/feature/corruption_ perceptions_index_2017\#table.

33. "Corruption in Kosovo: Bribery as Experienced by the Population," United Nations Office on Drugs and Crime (UNODC), 2011, https:// www.unodc.org/documents/data-and-analysis/statistics/corruption/ CORRUPTION_KOSOVO_Population.pdf.

34. That is the explicit comparison used in Capussela, State-Building in Kosovo.

35. See, for a wealth of detail on Kosovo, Arolda Elbasani, "State-Building or State-Capture? Institutional Exports, Local Reception and Hybridity of Reforms in Post-war Kosovo," Southeast European and Black Sea Studies 18, no. 2 (2018): 149-64, https://doi.org/10.1080/14683857.2018.1 475901 .

36. Arolda Elbasani and Senada Šelo Šabić, "Rule of Law, Corruption and Democratic Accountability in the Course of EU Enlargement," Journal of European Public Policy 25, no. 9 (2018): 1317-35, https://doi.org/1 $0.1080 / 13501763.2017 .1315162$.

37. Florian Bieber, "The Rise and Fall of Balkan Stabilitocracies," Center for International Relations and Sustainable Development, Winter 2018, https://www.cirsd.org/en/horizons/horizons-winter-2018-issue-no-10/ the-rise-and-fall-of-balkan-stabilitocracies.

38. Ivan Krastev, Shifting Obsessions: Three Essays on the Politics of Anticorruption (Budapest: Central European University Press, 2004).

39. Human Rights Watch, "The US Global Magnitsky Act: Questions and Answers," September 13, 2017, https://www.hrw.org/news/2017/09/ 13/us-global-magnitsky-act.

40. Adrian Shtuni, “The Western Balkans," Fikra Forum, January 29, 2015. For a comprehensive study and analysis see Anisa Goshi and Dallin Van Leuven, "Kosovo-Wide Assessment of Perceptions of Radicalisation at the Community Level," United Nations Development Programme in Kosovo, May 2017, http://www.ks.undp.org/content/dam/kosovo/ docs/PVE/UNDP_KS-Wide\%20Assessment_eng_web.pdf.

41. Srecko Latal, "Bosnian Serb Leaders Under Fire Over Loan," Balkan Insight, October 16, 2015, http://www.balkaninsight.com/en/article/ new-loan-for-bosnian-serb-entity-triggers-controversy-10-16-2015.

42. Regional Cooperation Council, South East Europe 2020: Jobs and Prosperity in a European Perspective, Report, November 2013, https:// www.rcc.int/files/user/docs/reports/SEE2020-Strategy.pdf. 
Open Access This chapter is distributed under the terms of the Creative Commons Attribution 4.0 International License (http://creativecommons.org/ licenses/by/4.0/), which permits use, duplication, adaptation, distribution and reproduction in any medium or format, as long as you give appropriate credit to the original author(s) and the source, a link is provided to the Creative Commons license and any changes made are indicated.

The images or other third party material in this chapter are included in the work's Creative Commons license, unless indicated otherwise in the credit line; if such material is not included in the work's Creative Commons license and the respective action is not permitted by statutory regulation, users will need to obtain permission from the license holder to duplicate, adapt or reproduce the material.

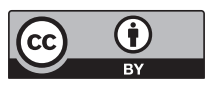

